مجلة جامعة الدلك عبدالعزيز: الآداب والعلوم الانسانية، م22، ص ص: 3-1071 (2015م/2015 1435هـ) DOI:10.4197 / Art.22-1

التحاجج والتتاظر : آدابُ التتاظر وآلياتُ كثف التغليط في نراث

$$
\text { ابن حزم الأندلسي (384 - 456هـ) }
$$

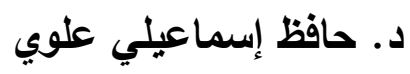

جامعة قطر

المستخلص. يسعى هذا البحث إلى تقديم تصوُر شامل لبعض شروط

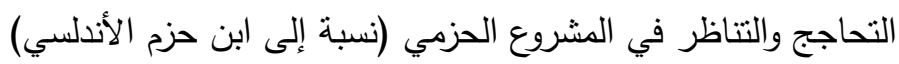

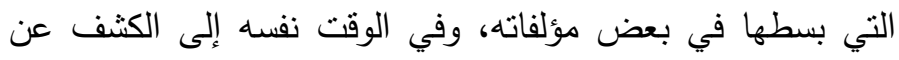

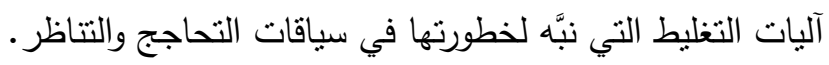

وغايتنا الأساس هي الكثف عن غنى الخطاب التراثي الإسلامي

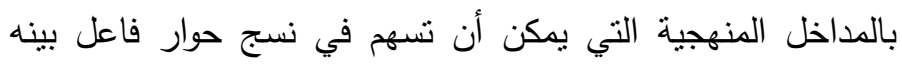

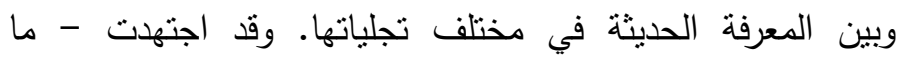
استطعت- في المزج بين: نتظيرات ابن حزم، وبين ما يتصل بها في في الدراسات الحجاجية المعاصرة، بعيدا عن الإسقاط، ولعبة المرايا (سواء أكانت محدَّبة، أم مقعرة).

الكلمات المفتاحية: التحاجج والتناظر في التراث الإسلامي ، ابن حزم

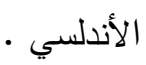




\section{ابن حزم الأندلسي}

ابن حزم - أو الإمام الأوحد، كما يحلو للبعض أن يلقبَّه- ظاهرة أندلسيَّة بامنياز ، عاث في زمن الصراعات والتتاقضات، ما بين ازدهار التفكير العلمي في الحضارة الإسلاميَّة والتراجع السياسي المخيف، وما بين عصر المنطق والفلسفة وحوار الأديان، فكان من الطبيعي أن يحملَ رؤيةً متميّزة لقضايا عصره، وأن يكون

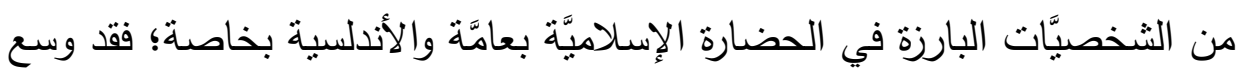
علمه كل فنون المعرفة؛ كيف لا وهو الفقيه، والمحدّث، والعالم بالملل والنحل، والمؤرّخ، والمتكلم، والفيلسوف، والمنطقي، وعالم النفس، والثاعر، والكاتب الأديب.

لقد فرض ابن حزم نفسَه على صفحات التاريخ بما تركه من آراء ومواقف وآثار علمية عكست بعمق خصوصيات عصره، وما تمبز به من صراع (الطبقات الاجتماعية والطبقات السياسية)، واختلاف (الملل والنحل)، وتعدّد (الأعراق والأجناس والقوميات). وكان لزاما على رجل من طينته أنْ ينخرطَ في قضايا عصره تلاك. وهذا ما عبَّرت عنه مناظراته وجداله مع الكثيرين من معاصريه؛ فقد ارتضى ابن حزم التتاظر والتحاجج منهجا، إلى درجة أنَّه كان يناظر ويحاجج كل

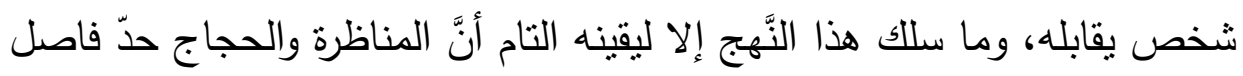
بين الصّدق والكذب، وأنها قناعة العقل واطمئنان القلب وسكون النفس(1)، وكانت غايته من ذلك: نصرة الدّين الإسلامي الحنيف، والدّفاع عن العقيدة الإسلامية

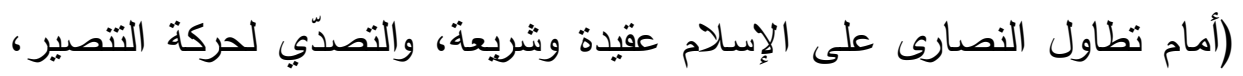
وتحامل اليهود وكيدهم للمسلمين). 
وعلى الرّغم من رسالته النبيلة، فقد لقي من عنَت أهله واضطهاد ذويه ما لم يلقه غيره، ولقي من أهل عصره أقسى ضروب الجحود والنكران. والأدهى والأنكى لهى أن يستمرَّ هذا الجفاء وهذا الجحود والنكران إلى اليوم، ولا نبالغ إذا قلنا إن ما لقيه النيه

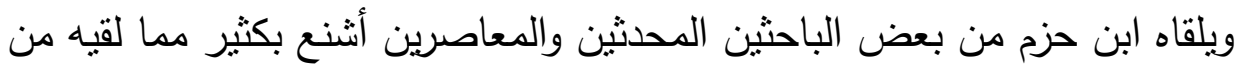

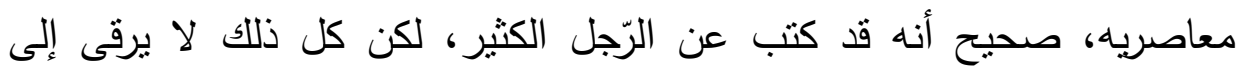

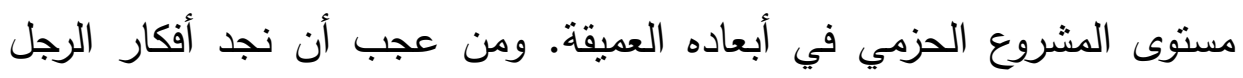

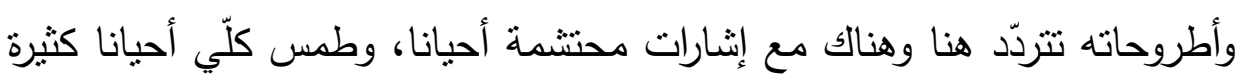

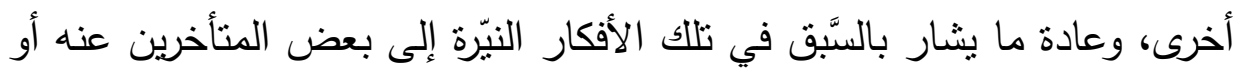
بعض المعاصرين، علما أنّ الإمام الأوحد كان له فيها فضل السبّق والرّيادة. ولا تدَّعي هذه الدراسة أن تأتي على كل ما كتبه ابن حزم، فهيهات لها ذللك،

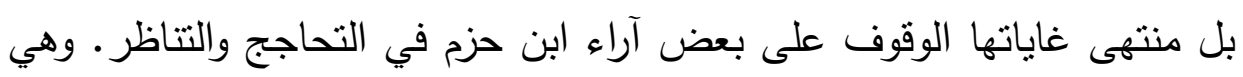

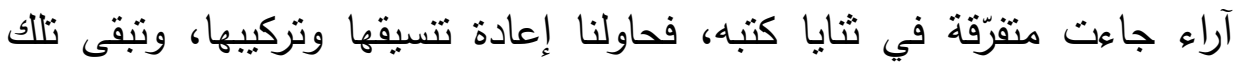
الآراء غيضا من فيض تراث الرجل الزَّاخر، كما تبتعد هذه الدراسة عن المقاربات

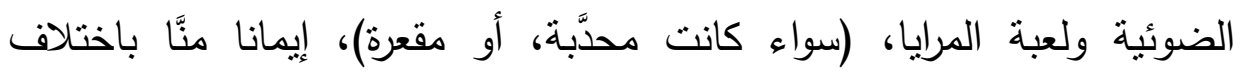
السيّاقات الفكرية، والمنطلقات الإبستمولوجية التي تحكم كل عملية نأليف. 1. الحجاج والجدال والتناظر : إثكال الحد والتعريف: تظهر المنهجية التحاججية التتاظرية في تعريفات المسلمين المختلفة للحجاج

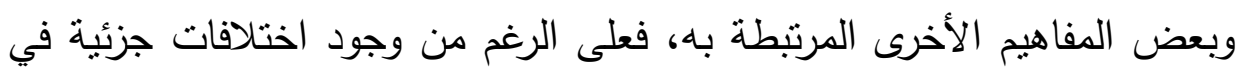

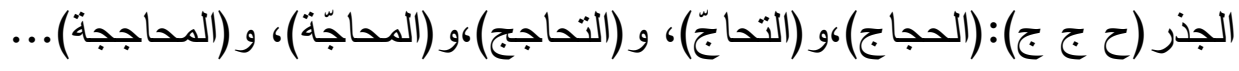

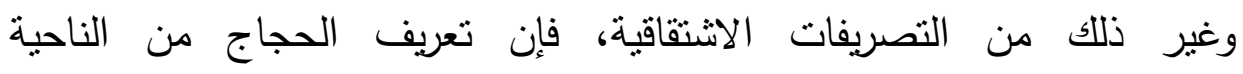

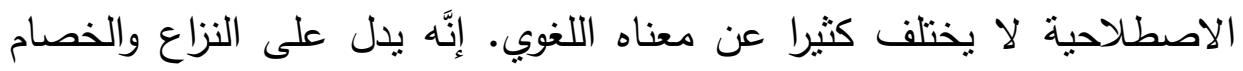
بوساطة الأدلَّة والبراهين والحجج، وهذا ما يلخصه تعريف ابن منظور : اهاجنته 
أحاجه حجاجا ومحاجة حتى حججته، أي غلبته بالحجج التي أدليت بها... وحاجه محاجة وحجاجا نازعه الحجة.... والحجة الدليل والبرهانه (1).

فابن منظور يجعل الحجاج مرادفا للجدل. فهو عنه ا(مقابلة الحجة بالحجة"(2)، ويؤكد هذا بقوله: 》هو رجل محجاج أي جدله|(3). وهذا ما نجده أيضا عند أبي الوليد الباجي الذي عنون كتابه، وهو كتاب في علم أصول الفقه، بـ المنهاج في ترتيب الحجاج، إلا أنه في المقدّمة وصفه بأنه لكتاب في الجدلهي". هذا الترادف بين الحجاج والجدل نجده في كتاب البرهان في علوم القرآن للزركثي (ت749هـ)(5) وكتاب الإتقان في علوم القرآن (6) للسيوطي (ت وخصوصا في الفصل الذي عقداه لجدل القرآن؛ إذ نجدهما يستخدمان في المنن ألفاظ "المحاجة" "والحجاج" "والاحتجاج" على أنها ألفاظ مرادفة للفظ الجدل، وتسد مسدَّه.

ويتذاخل مفهوم الجدل -من جهة أخرى- مع مفهوم المناظرة. فالمناظرة لغة مشتقة من النظر ومن الانتظار، ومن النظر بالبصيرة ومن النظير (7). ولما كانت

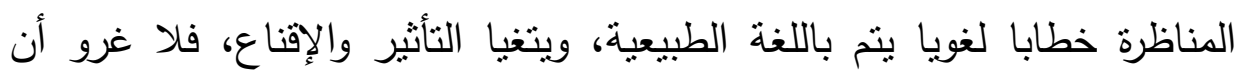
تكون بالضرورة خطابا حجاجيا، ولللك من الطبيعي أن نجد كلمات الجدال، والمناظرة، والحجاج تتبادل المواقع في بعض الكتابات.

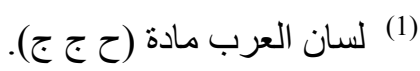

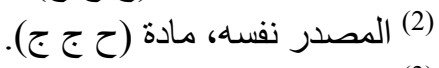

$$
\begin{aligned}
& \text { (3) المصدر نفسه، مادة (ج د ل) (لف ج). }
\end{aligned}
$$

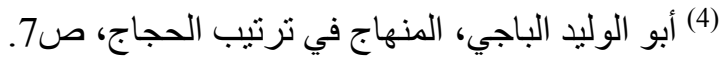

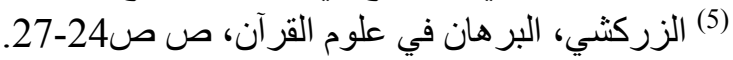

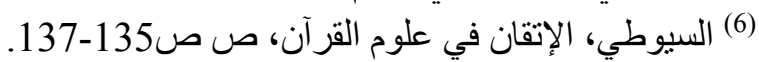

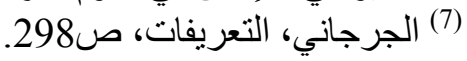


يؤكد هذا الترادف بين الحجاج والجدال من جهة، وبين الجدال والمناظرة من جهة ثانية، وبين المناظرة والحجاج من جهة ثالثة، أصل كلمة "جدل" في اللغة؛ إذ يمكن أن يكون "الجدل" مشتقا من "الجدل"، وهو الثدّة والإحكام. يقال جدلت الحبل أجدله جدلا: و"لا يشك أن في الجدل معنى الثد والإحكام لأن كلا من الخصمين يشتد على خصمه ويضايقه بالحجة التي اجته في إحكامها"، كما يمكن أن يكون من "الجدالة" وهي الأرض. يقال جدل الفارس قربنه إذا رماه بالجدالة أي أسقطه. وبافتراض هذا الأصل يكون "كل واحد من المتجادلين يقصد غلبة صاحبه وصرعه في مقام النطق كما يجدل الفارس قرينه"، وقد يكون من "المجدل" وهو القصر الذي يتحصن به، وبافتراض هذا الأصل يكون كل واحد من المتجادلين وكأنَّه "يتحصن من صاحبه بالحجة تحصن صاحب القصر به"، وقد يكون أيضا من "الجدول" وهو النهر الصغير، الذي يتفتل الماء فيه. وبهذا الأصل يكون كل واحد من المتجادلين وكأنه "يقصد فتل صاحبه عن رأيه فتل الماء في النهر"، كما يمكن أن يكون من "الأجدل" وهو الصقر • وبهذا الأصل يمنل المجادل بمن "يسطو بالحجة على صاحبه" مثلك في ذلك مثل الصقر الأجدل الذي يسطو

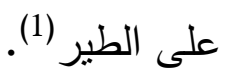

ويمكن أن ترد معاني الثد والإحكام والإسقاط على الأرض والتحصين والفتل والسطوة إلى معنى جامع كلي هو "معنى القوة والامتتاع والثند والإحكام"، وبذلك يكون الجدل مشتقا من هذا المعنى الجامع الكلي ومن كل واحد من جزئياته

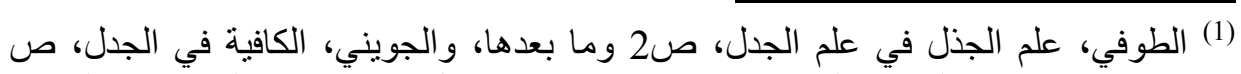

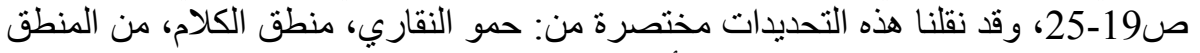

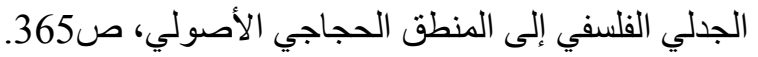


المذكورة، باعتبار ما يشتركان فيه من ذلك المعنى وما يختص به "الجدل" من

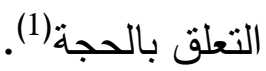

وأما اصطلاحا فيعني "المدافعة ليظهر الحق"؛ أي "دفع السائل قول المعلل ودفع المعلل قول السائل". وعلم الجدل هو العلم الذي "يعرف فيه صحيح الدفع وفاسده". وبعبارة أخرى: الجدل، كفعل، "رد الخصم عن رأيه إلى غيره بالدليل"، إنه قانون صناعي يعرف أحوال المباحث من الخطأ والصواب على وجه بدفع عن نفس الناظر والمناظر الثك والارتياب(2).

وعلى الرغم من هذا التداخل والترادف بين الحجاج والجدال الذي نقف عليه في التعريفات السابقة، فقد جرى استعمال الجدل في اصطلاح بعض أهل المناظرة

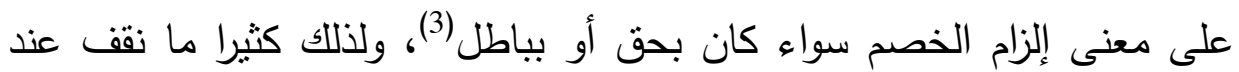
بعض السلف على تبخيسه وإبطاله، وربما كان ذلك بعد تعريب كتب اليونان، فاختلط على البعض معنى الجدل والمناظرة في الفكر الإسلامي بمعنى الكلمة اليونانية dailektike من حيث إن المعرفة المترنبة على هذه الكلمة ظنية في الفكر اليوناني(4)، وهذا على خلاف المعرفة المنرنبة على الجدل في الفكر الإسلامي، فهي معرفة يقينية تمثل الحق وتؤكده، وربما هذا ما دفع البعض إلى تحريم الجدل

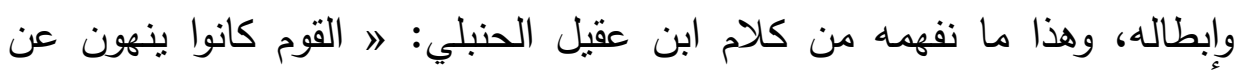

(1) حمو النقاري، منطق الكلام، من المنطق الجدلي الفلسفي إلى المنطق الحجاجي الأصولي، ص365.

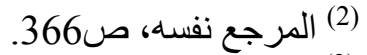

(3) التهانوي، كثاف الصطلاحات الفنون، ج1، ص232، و الغز الي، إحباء علوم الدين، ج 1، ص114. (4) (أميرة حلمي مطر ، تاريخ الفلسفة عند اليونان، ص5. 
الجدال، والجدال شُبه المتكلمينه(1)، وهذا ما أشنار إلبه أيضا ابن سينا بقوله:

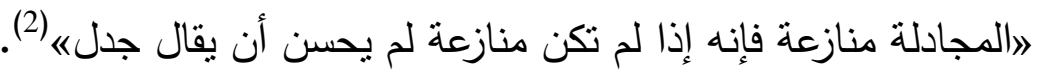

أما ابن حزم(3) فيعرف الجدال بقوله: اإخبار كل واحد من المختلفين بحجته، أو بما يقدر أنه حجته، وقد يكون كلاهما مبطلا، وقد يكون أحدهما محقا والآخر مبطلا، إما في لفظه وإما في مراده، أو في كليهما، ولا سبيل أن يكونا معا محقين في ألفاظهما، ومعانيهماه (4).

ونظرا إلى أهمية الجدل في المنهج الحجاجي الجدالي عند ابن حزم، فقد توقف مطولا على مسألة تحريم الجدال في الثقافة العربية الإسلامية، وعبر عن إن موقفه من ذلك بوضوح، يقول: 》 وقد احتج من أبطل الجدال والمناظرة بقوله

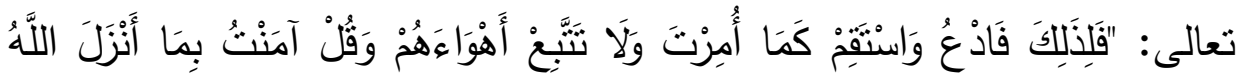

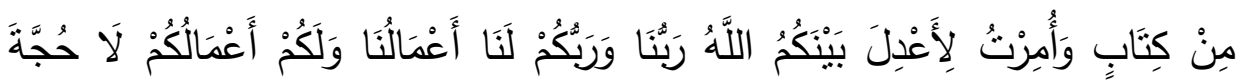

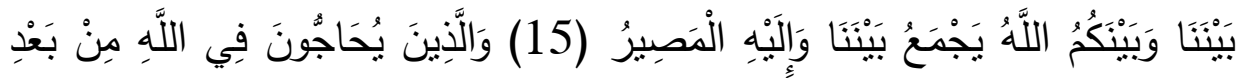

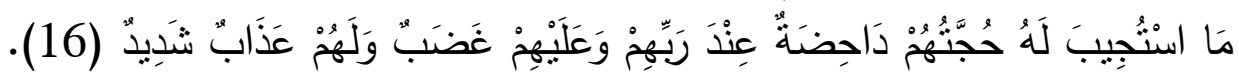
(الثورى: 15-16) (15) (5)

فهاتان الآيتان، بحسب ابن حزم، مبينتان لوجه الجدال المذموم، وهو قوله تعالى فيمن يحاجج بعد ظهور الحق، وهذه صفة المعاند للحق، وهذا مذموم عند كل ذي عقل. فقد ذمّ الله تعالى الجدال بغير حجة والجدال في الباطل؛ وهذا يعني

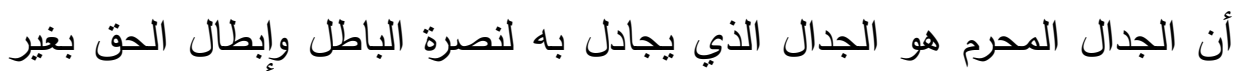

$$
\begin{aligned}
& \text { (1) ابن عقيل الحنبلي، الآداب الثرعية، ج 1، ص204. }
\end{aligned}
$$

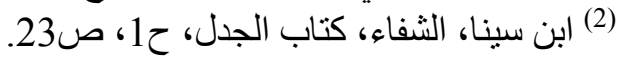

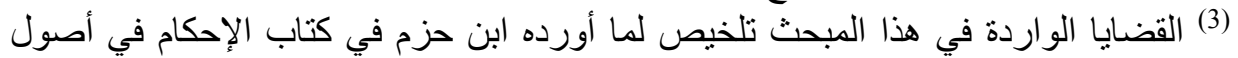

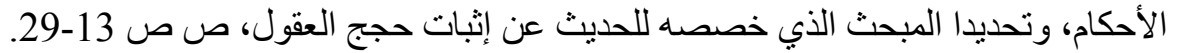

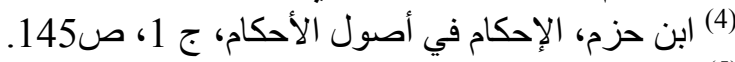

$$
\begin{aligned}
& \text { (5) المرجع نفسه، الصفحة نفسها. }
\end{aligned}
$$


علم. وهذا النوع من الجدال وجهان: أحدهما من يجادل بغير علم، والثاني من يجادل ناصراً للباطل بشغب وتمويه بعد ظهور الحق إليه.

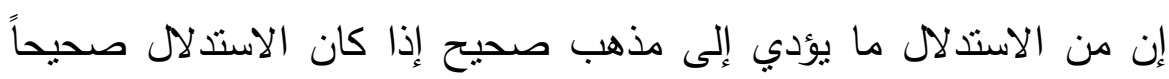

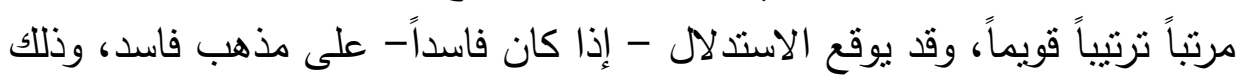
إذا خولف به طريق الاستخلال الصحيح.

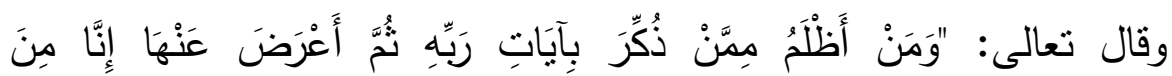

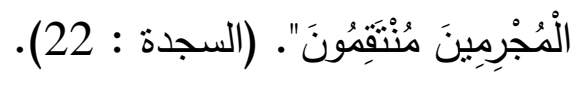

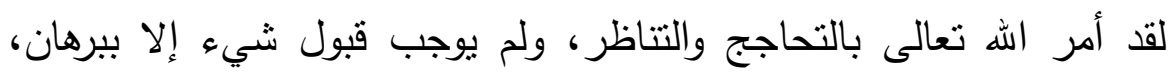

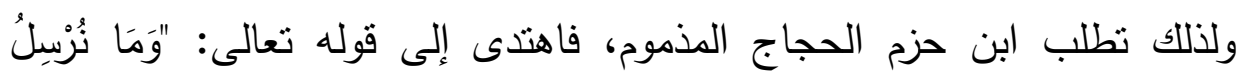

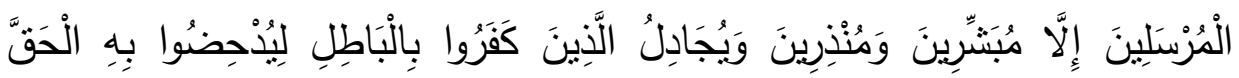

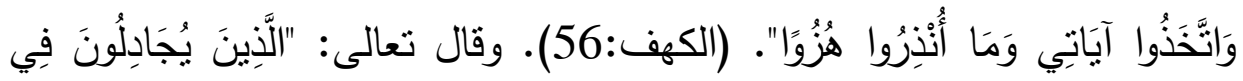

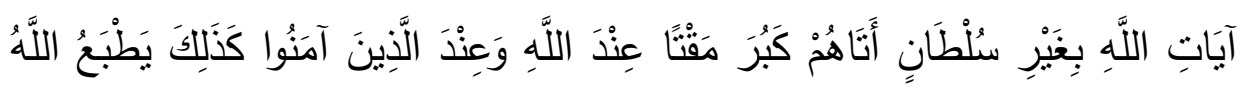

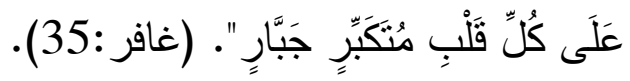

فقد بينت هذه الآيات وجوه الجدال الدذموم، والجدال المحمود الواجب،

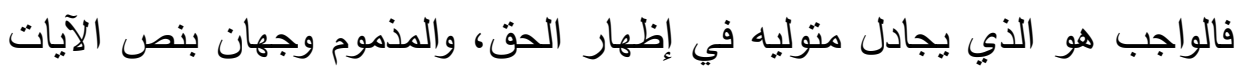

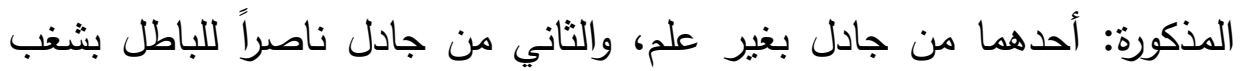

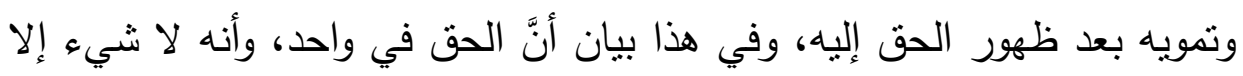

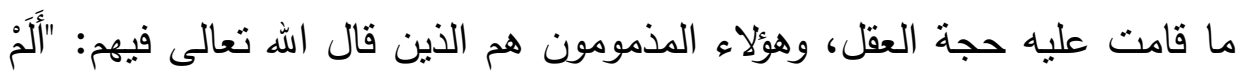

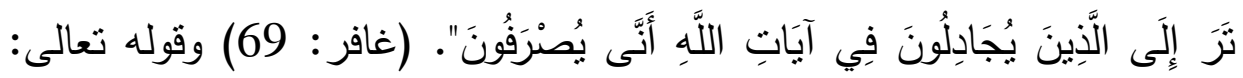

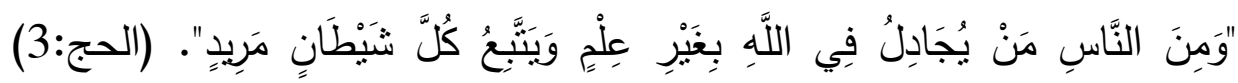

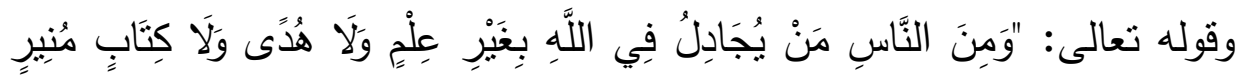

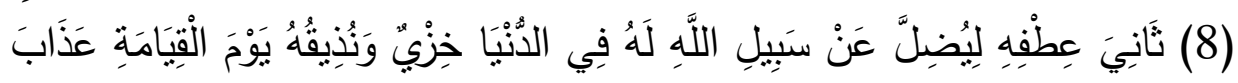




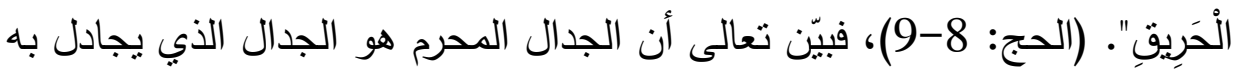

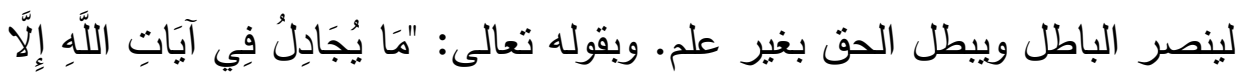

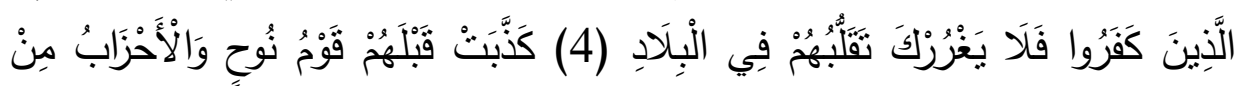

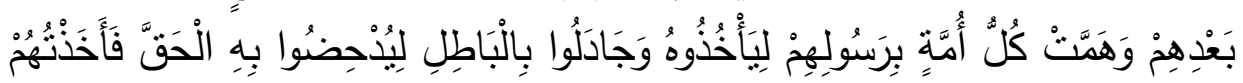

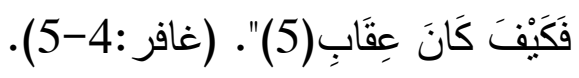

ويجد ابن حزم في الآيات السابقة أمرا واجبا بالمناظرة كايجاب الجهاد والنفقة

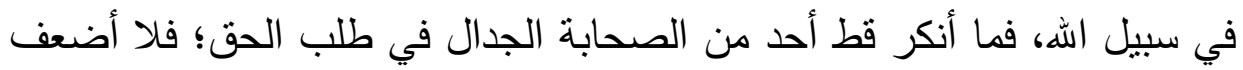

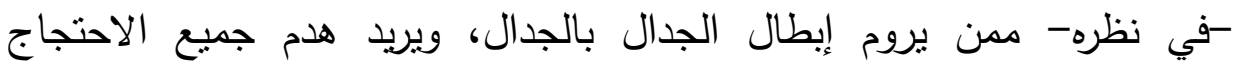

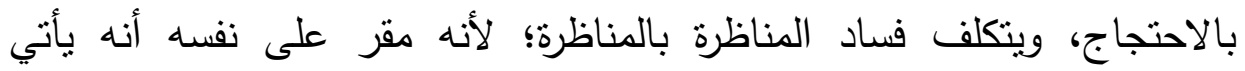

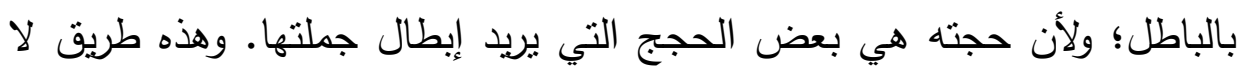

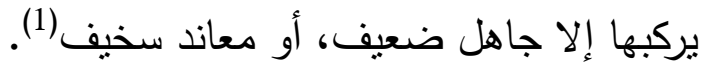

يكثف التحليل السابق عن تحديد واضح للجدال المحمود والجدال المذّوم

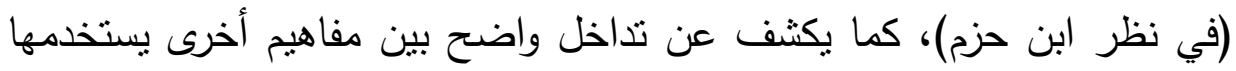

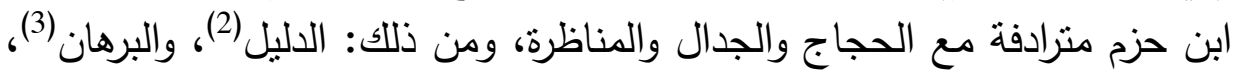

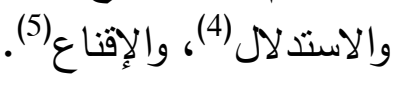

إن تمييز ابن حزم بين الحجاج المدوح والحجاج المذموم سيأخذ قسطا وافرا

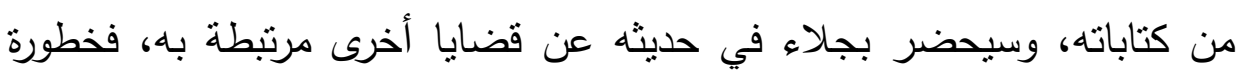
الجدال المذموم فرضت عليه أن يخصص مباحث كاملة من بعض كتبه كنبه للحديث

(1) المرجع نفسه، الصفحة نفسها.

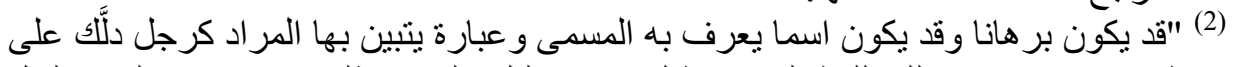

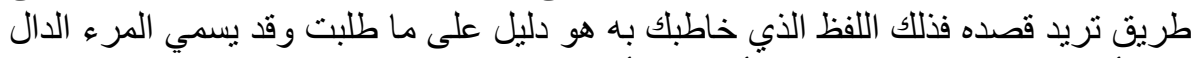

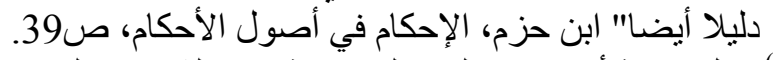

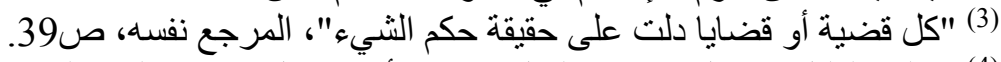

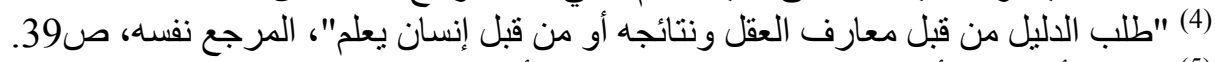

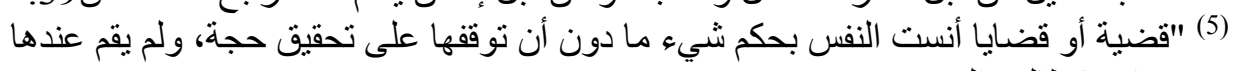

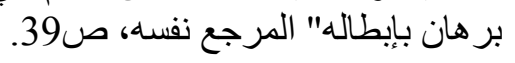


عن الطرق التي يتم بها، كما أن أهمية الجدال المحمود جعلته يبحث عن الوسائل التي يتحقق بها، وهذا ما سنبرز بعض تجلياته من خلال حديث ابن حزم عن المغالطة وآليات كثفها، والمناظرة وآدابها.

2. كشف المغالطات: السبيل المعلوم إلى إبطال الجدال المذموم: لما كان الجدال بالباطل مذموما منهيا عنه بالكتاب والسنة، فقد كان من

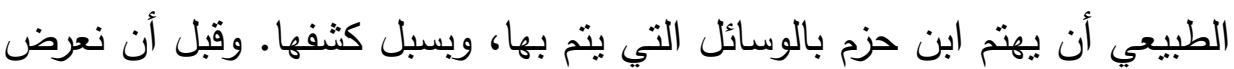
لمنهج ابن حزم في كثف المغالطات، لا بد من الوقوف على بعض التعريفات التي تصدت لهذا الصنف من الحجاج، وبينت خطورته وزيفه(1). فالمغالطة نمط فاسد من الحجاج، ولكنه بيتعمل على نحو غير مناسب، وهذا ما يفيده المعنى اللغوي للكلمة؛ فالغلط أن تعيا بالثيء فلا تعرف وجه الصواب فيه، وقد غلط في الأمر يغلط غلطا وأغلطه غيره ... والغلط كل شيء يعيا الإنسان عن جهة صوابه من غير تعدد. وقد غالطه مغالطة. والمَغلطة والأغلوطة: الكلام الذي يغلط فيه ويغالط به؛ ومنه قولهم: حدَّثه حديثا ليس بالأغاليط. والتغليط: أن تقول للرجل غلطت والمغلطة والأغلوطة: ما يغالط به من المسائل، والجمع الأغاليط. فأما الأغلوطات فهي جمع أغلوطة(2). وتجمع التعربفات التي أعطيت للمغالطات على أنها استدلالات فاسدة أو غير صحيحة، تبدو وكأنها صحيحة؛ لأنها مقنعة سيكولوجيا، لا منطقيا، وذلك لاختفاء هذا الغلط وراء الغموض اللغوي أو الإثارة العاطفية، أو لعدم الانتباه إلى ما به من

(1) نعرض هنا لبعض القضايا العامة المرتبطة بالمغالطات، ويمكن أن يجد القارئ تفصيلا لذلك إلك

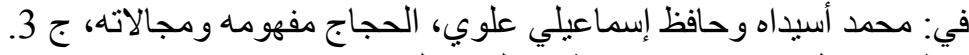
(2) انظر هذه المعاني في: ابن منظورة، لسان العرب، العباء 
مخالفة للقواعد المنطقية، ولذلك لا يظهر فساده أو عدم صحته إلا بالفحص الدقيق.

ويذهب والتن دوغلاسWalton.N.D إلى أن وصف المغالطات (Sophismes) من حيث هي حجج تبدو صالحة، في حين أنها ليست كذللك. إنها تخصيص غير كاف وخادع. فالمغالطات هي حيل تقوم على أنماط من الحجاج صحيحة، ولكنها تستعمل على نحو غير مناسب، حيث يتم قطع التواصل وتشويش قنوات الحجاج الاستدلالي (الذي تستدل به جماعة لأجل بلوغ هدف مقبول)، وتبعا لهذا التصور (الذي ينطلق من وجهة نظر تداولية) ، فإن المغالطة لا يمكن أن تفهم وتقوم على نحو سليم إلا في علاقتها بجماعة المتحاجين الذين يلتزمون جماعة ببنية عرفية أو مؤسسية لحوار تفاعلي محكوم بقواعد (1).

تكثنف هذه التحديدات عما تتطوي عليه المغالطة من خداع وتدليس ومناورة وسفسة. فهي تبدو في صورة استذلال أو قياس صحيح ومستقيم لكنه فاسد وسقيم في حقيقته. أما الذي يستخدم منل هذا الاستذلال الفاسد فيسمى سوفسطائيا، مادام لا يحتج ولا يستدل من أجل الوصول إلى الحقيقة، بل من أجل دحض هل منافسه مع تعدد تضليله، وقصد خداعه ومحاولة إخفاء الحقيقة عنه. فإذا كان الحجاج في معناه السوي؛ أي باعتباره مظهرا من مظاهر التفاعل اللغوي الجدلي، يشهد على سيادة ثقافة الحوار والتواصل التي تقوم على الانتصار لرأي ما والدفاع عنه بالحجج العقلية وبوسائل الإقناع والإفحام، فإنه ينزاح أحيانا عن هذه الغايات؛ فبدلاً من الاحتكام إلى العقل والمسلمات المشتركة، يتم اللجوء لراء أحياناً إلى الاستمالة والمشاحنة والمغالطة والعنف والتطرف والإقماع والمواربة

Walton. N. D. Les violations des régles du dialogue raisonné in Parret. H, p245. - (1) 
والتمويه والحيلة والتضليل والتعتيم والإيهام والمكيدة. فينقلب الحجاج بكل ذلك إلى عنف يمارس بطرائق شتى، فيخرج من دائرة الحوار التعاوني المنتج ويتحول إلى تواصل إعناتي عقيم، وينقلب بذلك من حجاج عقلي إلى جدال مذموم (بتعبير ابن حزم).

ونظرا إلى خطورة هذا النوع من الحجاج المغالط في تكريس ثقافة اللاحوار، فقد انبرى مجموعة من الباحثين للتبصرة بالمغالطات؛ ولذلك لا نعجب إذا وجدنا للمغالطات آباء قدامى يأتي في مقدمتهم أفلاطون في محاورة "يوثيديموس" Euthhydemus القرون التالية فلاسفة كثيرون من أبرزهم: جون لوك John Locke، وواتلي Whatley وشوبنهاور Schopenhauer، وجون سنيوارت مل:John Stuart Mill، وجريمي بنتام Jeremy Bentham، وجون وودJohn Wood، وولتون دوغلاس - Douglas Walton

وتحضر منل هذه النظرة وهذه المواقف من السفسطة في التقافة العربية الإسلامية، فهذا ابن رشد يصف القول السفطائي بالخبث(1)، ونظر السجماسي وهني إلى التشكيكات التي تحدث عنها في "جنس المظاهرة" على أنها 》 منالات جزئية سفسطائيةه (2).

أما ابن حزم فقد تحدث عن الثعاب والعوارض التي يقع بها التغليط ، ونبه إلى خطورة المغالطات، وبين أنماطها، ووجوه الغلط الممكنة فيها، في محاولة منه لرصد كل أشكال التتويش على الحوار التتاظري، وهي الأشكال التي تحول دون سلك سبل الإقناع التي تقوم على صحة الأدلة، وتحمل عبء الإثبات، ولا يكف 
ابن حزم في كتاباته عن الدعوة إلى تجنب الوقوع في شرك المغالطين، والحث على ضرورة تجنب مواقع التغليط، وهذا ما تكثف عنه عبارات تتكرر بشكل ملفت في مؤلفاته، وخصوصا في كتابه التقريب لحد المنطق(1)، ومن ذلك قوله(2):

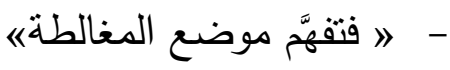

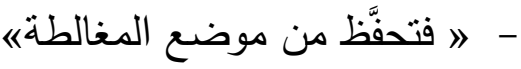

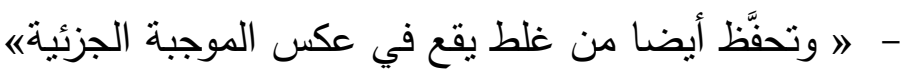

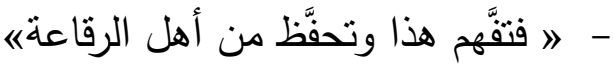

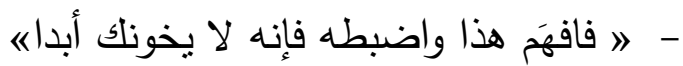

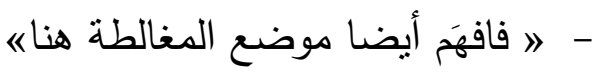

$$
\begin{aligned}
& \text { - " وينبغي أن تتحفَّظ من أغاليط شغب بها مشغبون وقحاء《هاء... }
\end{aligned}
$$

وعلاوة على ذلك، يدعو ابن حزم إلى عدم الالتفات إلى أهل الثغب؛ لأن

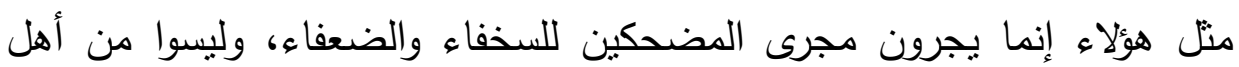
الحقائق أصلا (3)، كما أن أعظم سلاحهم التلبيس(4).

إن التصدي للمغالطين هو سبيل التحفظ: \... من تخليط كل من لا يتقي الله - عز وجل - في السعي في إفساد الحقائق من المدلسين الذين هم أحق بالنكال من المدلسين في النقود والبيوع، وقد قال رسول الله صلى الله عليه وسلم: "من غشنا فليس منا"، ولا غش أعظم من غش في إبطال الحقائق...《(5).

(1) نحيل القارئ هنا تحديدا على الفصل المعنون: أغاليط أوردناها خوفا من تشغيل مشغب بها

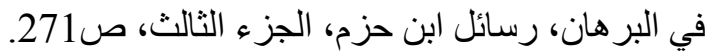

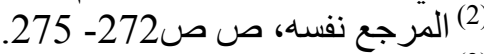

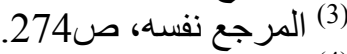

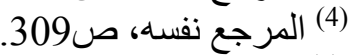

$$
\begin{aligned}
& \text { (5) المرجع نفسه، ص273. }
\end{aligned}
$$


ولم يكتق ابن حزم بهذه التتبهات على خطورة التغليط، بل عمد إلى تبيين طرائق الاستدلال الصحيح، وتمبيزها عن طرائق الاستدلال الفاسد، بغاية كثف الثعاب والعوارض التي يقع بها التشغيب (التغليط)، وغايته من كل ذلك أن يبين: ״ا.... يحتاج إليه من بيان البرهان الصحيح وذكر جمل الجدليات الفاسدة والثغبيات الساقطة وبيان كثير منها بمقدار ما يميزها به الطالب إذا رآها...ی)(1). ويمكن تقسيم المغالطات التي تحدث عنها ابن حزم إلى: مغالطات تهم عكس القضايا، ومغالطات تهم الثكل الأول أو الثكل الثاني من أشكال القياس، ونوع ثالث يهم الأقوال عامة (الزيادة، النقصان، إلخ).

\section{2. مغالطات عكس القضايا:}

1. 1. 2. مغالطة عكس إن النافية للجنس نافية كلية: ومثال ذلك قول قائل: لا فارسي إلا أعجمي، فهذا حق، وعكسها لا أعجمي إلا فارسي، وهذا كذب، فهذه القضية موجبة لا نافية وإن كان ظاهرها النفي. ويزيد ابن حزم ذلك بيانا فيقول: ألا ترى أنك قد أوجبت العجمة لكل فارسي؟ فهذه موجبة كلية وليست نافية البتة، وإذ هي كذللك فعكسها موجبة جزئية، وهي قولك: وبعض الأعجمين فارسي (2). فوجه الغلط هنا يكمن في عدم احترام الثروط المنطقية المتعلقة بعكس القضايا. فتطبيق العكس على الكلية السالبة لا يصدق إلا بالتباين الكلي بين الموضوع والمحمول، وبالتالي، فالمنباينان لا يجتمعان. ومن ثم، يصح سلب كل منهما عن جميع أفراد الآخر . فموضع الغلط هنا أن النفي ظاهري فقط. 
2. 1. 2. المغالطة الواقعة في عكس الموجبة الكلية: كأن يقول قائل: أليس

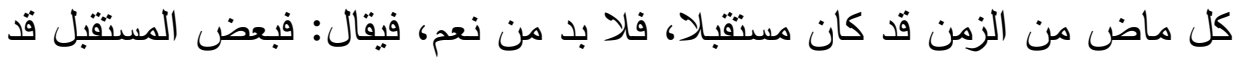

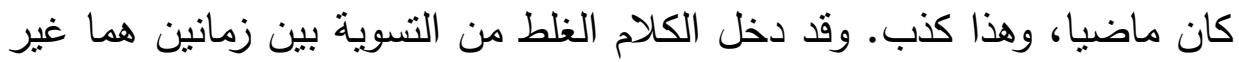
الصفتين اللتين هما المضي والاستقبال، المضي خبر عن شيء كان موجودا حال المستقبل، لأن المستقبل عدم ولا حال للعدم، ويقتضي لفظ المخبر عنهما

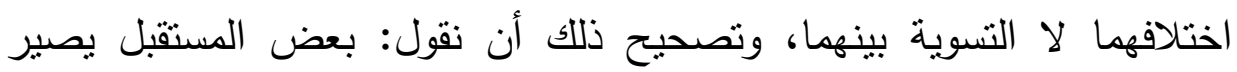

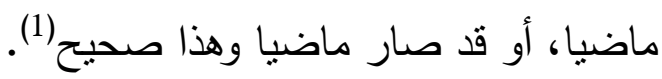
3. 1. 2. المغالطة الواقعة في عكس الموجبة الجزئية: وذلك في مثل قول قائل: بعض الخمر قد كان عصبرا، فإن قيل: بعض العصير قد كان خمرا فهو كذب. والغلط أيضا ها هنا من قبل التسوية بين زماني المخبر عنهما، وزمانهما غيرهما، وإنما يصح العكس في الصفات الملازمة للمخبر عنهما لا في الصفات

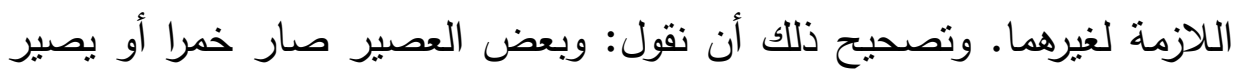
خمرا (2)

2. 2. 2. مغالطات تهم الثكل الأول أو الثكل الثاني من أثكال القياس: 1. 2. 2. 2. مغالطات الثكل الأول من أثكال القياس:

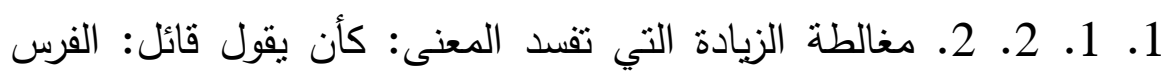

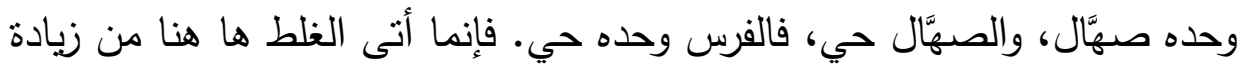

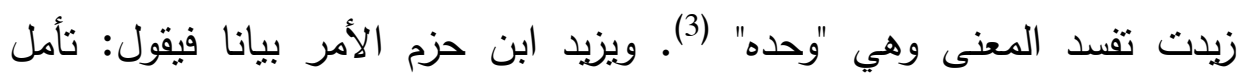

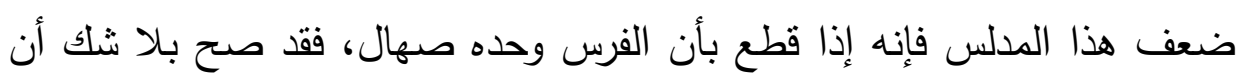


الصهال وحده فرس، لأن الصهيل صفة مساوية للفرس ليست أعم منه، فلما أتى هذا المدلس بقضية توجب أن الصهال وحده فرس قال: والصهال حي، بعد أن شرط انفراد الصهال بالفرسية، وأدرج في قوله الصهال حي أنه الصهال المراد بالذكر في المقدمة الأولى، فأوجب برتبة لفظه أن وصف الصهال بالحياة وصف مساو لا أنه وصف أعم، فصار قائلا الصهال وحده حي، فهذه المقدمة الثانية مموهة، وهي كاذبة؛ لأنها وضعت موضع كذب وشبهت بالحقائق، فلكذب المقدمة كذبت النتيجة. فكذب المقدمة الثانية إنما كان لأنه بناها كلية اللفظ على موصوف هوه جزئي، وإنما كان الصواب أن يقال في النتيجة فالفرس حي، ولا يذكر "وحده" لأن "وحده" في الحقيقة مع "صهَّال" خبر عن الفرس، وليس لفظ "وحده" تابعا للفرس فيذكر في النتيجة، لكنه تابع للصهال -وهو الحد المشترك- ولو ذكره في المقدمة الثانية مع الصهال فقال الفرس وحده صهال، وهو وحده صهال حي، فالفرس حي

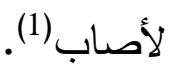

2. 1. 2. 2. مغالطة الربط(2): ومن ذلك أن أحد المغالطين سأل طبيبا فقال له: الحرُ يحلل؟ قال له نعم، فقال له: والبرد يحلل؟ قال له نعم، فقال له: فالحر هو البرد والبرد هو الحر، فقال له الطبيب: إن وجهي تحليلهما مختلف وليس من أجل اتفاقهما في صفة ما وجب أن يكون كل واحد منهما هو الآخر، فلج المشغب 
وأبى، فلما رأى الطبيب جنونه وتراقعه قال له: أنت حي قال نعم قال: والكلب

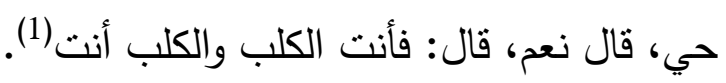
فاتفاق أمرين في شيء ما لا يعني أنهما يتفقان من جميع الوجوه؛ لأن الاتفاق لا بعني التكافؤ أو المماثلة.

2. 2. 2. مغالطات الثكل الثاني من أشكال القياس:

1. 2. 2. 2. مغالطات المقدمات النافية نفيا مجردا: ومثال ذلك قول من يريد التغليط: ممتتع أن يكون الإنسان حجرا، وممتتع أن يكون الحجر حيا، فهاتان

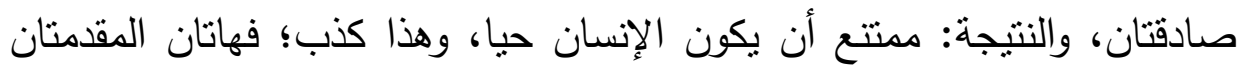

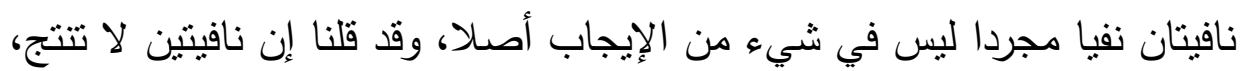

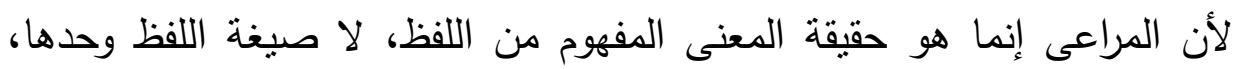
وهاتان المقدمتان وإن كانتا بلفظ الإيجاب فمعناهما النفي المجرد المحض؛ لأني أنهما نفتا عن الإنسان الحجرية وعن الحجر الحياة، ولم توجبا للحجر ولا للإنسان معنى أصلا غير ما أوجبه لهما اسماهما فقط. ووجه المغالطة أنها لا تحترم القانون المنطقي الذي يقول لا إنتاج من سالبتين.

2. 2. 2. 2. مغالطة سوء النظم: كأن يقول قائل: كل نهاق حي، ولا واحد من الناس نهاق، فهاتان صادقتان، النتيجة: فلا واحد من الناس حي، وهو كذب (2) - nن.

فالمغالطة ناتجة عن عدم احترام شروط التأليف، فلم تحترم الثرط الذي يقول بأن الحد الأوسط يجب أن يكون محمولا في المقدمتي؛ لأن هذا يخل بشروط الاستغراق. 
3. 2. 2. 2. مغالطة إسقاط شيء من الموصوف: ومن ذللك القول: الشعر

غير موجود في شيء من العظام، والعظام موجودة في كل إنسان فهاتان صادقتان، النتيجة: فالثعر غير موجود في شيء من الإنسان، وهذا كذب، وهذه مغالطة قبيحة؛ لأن الموضوع وهو المخبر عنه المقصود بالوصف في المقدمة الأولى إنما هي العظام، لأنه عنها نفى الثُعر ثم أثبت ذكر العظام في المقدمة الثانية في أن وصف مكانها فقط. والصواب: فالثعر ليس في شيء من عظام الإنسان، وأيضا فإن قوة هاتين المقدمتين قوة جزئية لأن العظام بعض من أبعاض الإنسان وليست كل الإنسان، والثعر إنما هو في بعض الإنسان لا في كله.

\section{2. 2. مغالطات تهم الأقوال بصفة عامة:}

1. 3. 2. مغالطة إسقاط قسم من الأقسام: كأن يقول قائل: لا يخلو هذا اللون من أن يكون أحمر، أو أخضر، أو أصفر، أو أسود (بعد إسقاط: الأبيض، والأزرق، وغير ذلك)(1).

3.3.2 ريادة قسم فاسد من الأقسام: لا يخلو هذا الثيء من أن يكون هو

$$
\text { هذا الثيء أو هو غيره، أو لا هو ولا غيره، فهذا قسم فاسد زائد(2). }
$$

3. 3. 2. مغالطة اشتباه الأسماء: ويكون من جاهل ومن عامد، أما الجاهل

فمعذور ، وأما العامد فمذموم، ويشبه ابن حزم غلط الجاهل بغلط عدي بن حاتم إذ سمع الآية: "وكلوا واشربوا حتى يتبين لكم الخيط الأبيض من الخيط الأسود". (البقرة: 187) فظنها من الخيوط المعهودة. وأما العامد فنحو الذين قيل لهم "راعنا" من المراعاة فقالوا راعنا من الرعونة(3). 
4. 3. 2. مغالطة تصحيح شيء وبطلانه ببطلان شيء آخر بلا برهان يوجب إضافتهما: من السفسة تصحيح شيء بتصحيح شيء آخر، وبطلانه ببطلان شيء آخر، بلا برهان يوجب إضافتهما. فذلك فاسد جدا. ومن ذلك أن يقول القائل: لما صح التحريم في البُر بالبر متفاضلا، صح التحريم في الأرز بالأرز متفاضلا. وهذا كله تحكم ودعوى. وليس يعجز أحد عن ربط شيء بشيء لا رباط بينهما بلسانه إذا استجاز القطع بما اشتهى. وكقول من قال من العميان: لو كان اللون مرئيا لكان العقل مرئيا، فلما كان العقل غير مرئي وجب أن اللون غير مرئي، فتأمل هذا كله تجده بهنانا وجهلا ودالة في غير موضعها كدالة الصبيان على آبائهم ولا فرق(1).

\section{3. آداب التناظر عند ابن حزم:}

ليس التتاظر عند ابن حزم ترفا، بل هو أمر واجب ،كايجاب الجهاد، والنفقة في سبيل الله: "... فمن ينهى عن المناظرة والحجة فليعلم أنه عاصٍ لله - عز وجل- ومخالف لملة إبراهيم، ومحمد صلى الله عليهما..."(2..

فلما كان هذا موقف ابن حزم من المناظرة، كان من الطبيعي أن يضع للمناظرة آدابا وضوابط صيانة لها عن أن تتحول إلى جدال مذموم ومماراة بعيدة هون عن نشدان الحقيقة، ونحو ذللك مما يفسد القلوب، ويهيج النفوس، ويورث التعصب، ولا يوصل إلى الحق (3).

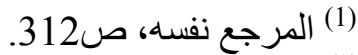

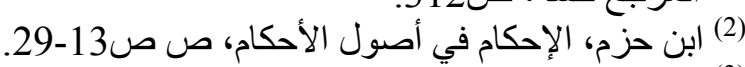

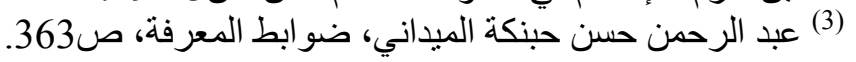


إن الوصول إلى الحق لا يكون إلا بالإنصاف، ولذلك كان الإنصاف غاية العدل في المناظرة، فحدد ابن حزم شروط التناظر التي يتحقق بها هذا الإنصاف (1). (1)

ويمكن أن نميز في آداب التناظر تللك وشروطه بين:

\section{3. الثروط التمهيدية الخارجية:}

هذه الثروط هي أقرب إلى التوجيهات الخلقية والتنبيهات الحِكَية التي تسهم في تكثير العوامل المثمرة للتناظر المفيد والقويم، ومنها:

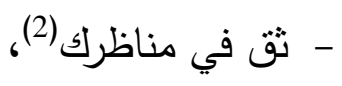

- لا تبال بكثرة خصومك ولا بقدم أزمانهم ولا بتعظيم الناس إياهم ولا بعزتهم،

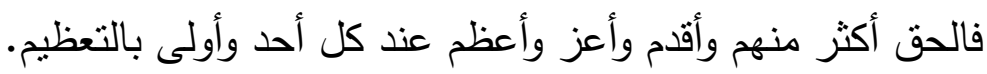
- لا تلتفت إلى دن يتبجح بقدرته في الجدل فيبلغ به الجهل،

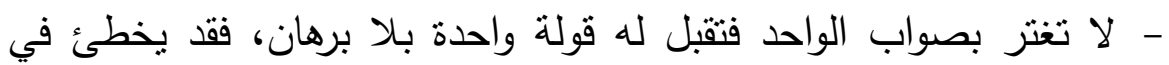
خلال صوابه في ما هو أبين وأوضح من كثثر مما أصاب فيه، - لتكن رغبتك في أن تكون محقا عالما عاقلا غالبا في الحقيقة، - احذر مكالمة من ليس مذهبه إلا المضادة والمخالفة أو الصياح والمغالبة، - احذر الغضب، وإذا ورد عليك خطاب بلسان، أو هجمت على كلام في كتاب، فاياك أن ثقابله مقابلة المغاضبة الباعثة على المغالبة، قبل أن تتبين

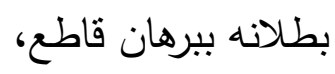

(1) وهو الفصل الذي عنونه ابن حزم: باب الكلام في رتب الجدال والمناظرة وكيفية المناظرة

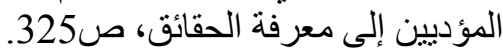

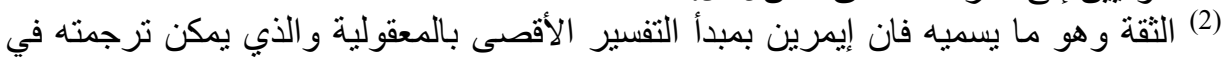

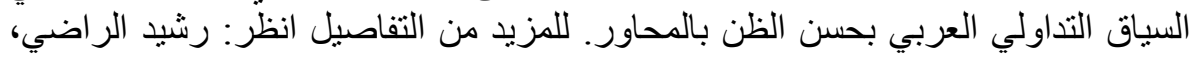

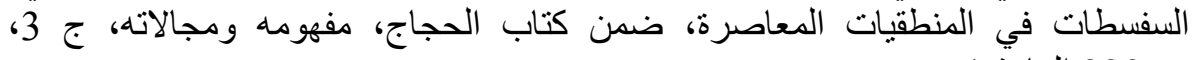




$$
\begin{aligned}
& \text { - تحفظ من إجابة من لم بسألك؛، } \\
& \text { - لا تتكلم في علم من العلوم حتى تتبحر فيه، } \\
& \text { - إياك والامتذاح بما تحسن، } \\
& \text { - لا تحقر أحدا حتى تعرف بما عنده، }
\end{aligned}
$$

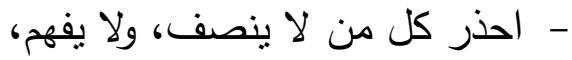

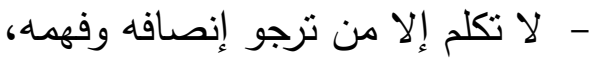

$$
\begin{aligned}
& \text { - ل التتكلم إلا في إبانة حق أو استبانته، } \\
& \text { 2. 3. الشروط التفاعلية الداخلية: }
\end{aligned}
$$

وهي شروط نتعلق بالطور الحجاجي الفعلي، ويمكن التمييز فيها بين:

1. 2. 3. المقتضيات التدبيرية الصورية:

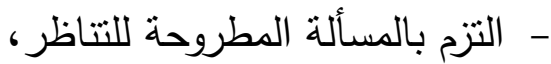

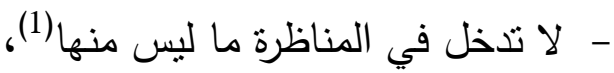

- اجعل سؤالك سليما من النقص والإشكال (2)، - - لا تطل الكلام بلا فائدة،

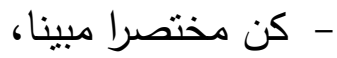

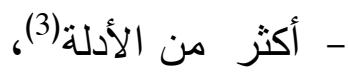

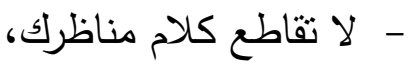
- احذر من أن تجيب نفسك عن خصمك، منكاف

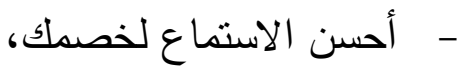

يمكن رد هذه القاعدة والقاعدة التي قبلها إلى القاعدة الثالثة من القواعد الجدلية النموذجية

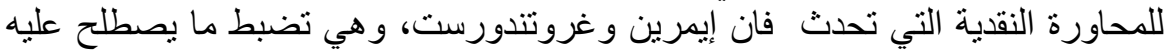

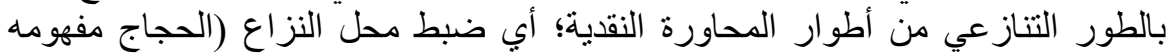

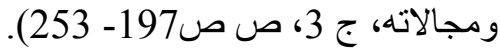
ترتبط هذه القاعدة والقاعدتان المواليتان لها بمنطق التخاطب كما عرض أصوله بوله

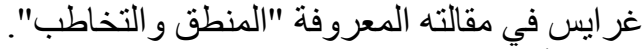
تكثير الأدلة تفرضه طبيعة الحبروة الحنطاج الظنية، بينما يكتفى في البر هان بدليل و احد. 
- تحفظ من الخروج من مسألة إلى أخرى قبل تمام الأولى وبيانها 2. 2. 3. المقتضيات المضمونية: - لا ترض لنفسك من خصمك، ولا من نفسك لخصمك إلا بالحق الواضح،

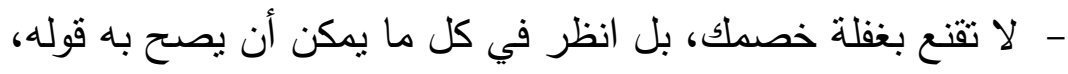

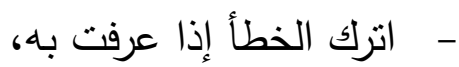
- تجنب معارضة الخطأ بالخطأ،

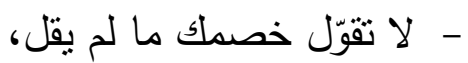
- أنصف خصمك بتقصي حججه، 3. 3. ضوابط الختم: الطور الختامي: - اقنع من خصمك بالعجز عن أن بنصر قوله، ولا تطالبه بالإقرار بالغلبة، فليس ذلك من فعال أهل القوة،

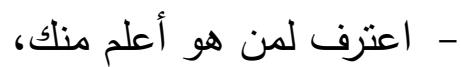
- - إن وجدت حقا ببرهان فارجع إليه ولا تتردد، ولا ترض لنفسك بيقاء ساعة

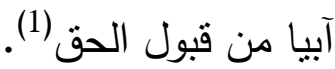

إن الالتزام بهذه الثروط أمر صعب، ولا يمكن أن يقدر عليه إلا بخصلة واحدة وهي ترويض النفس على قلة المبالاة بمدح الناس أو ذمهم، والوكد في

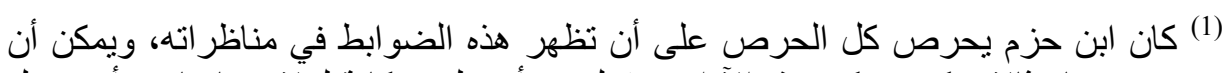

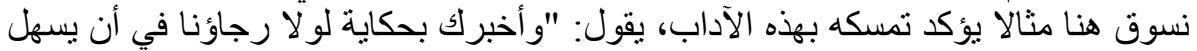

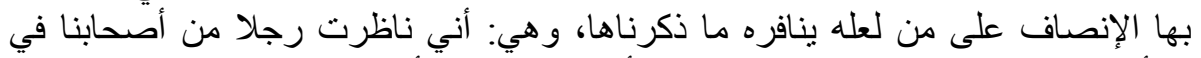

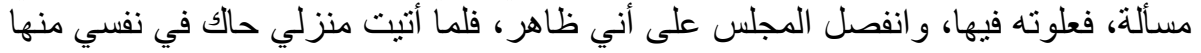

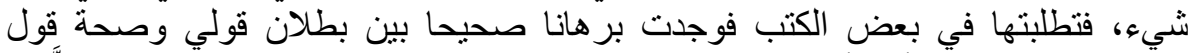

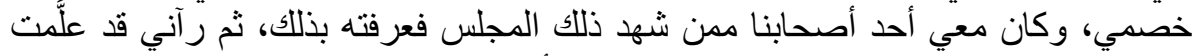

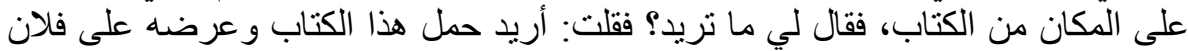

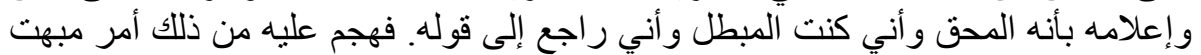

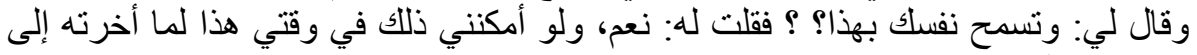

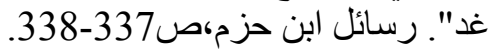


طلب الحق لنفسه فقط(1)، وطلب الحق لا يكون إلا بشدة البحث، وشدة البحث لا تكون إلا بكثرة المطالعة لجميع الآراء والأقوال، والنظر في طبائع الأشياء، وسماع حجة كل محتج والنظر فيها وتفتيشها، والإشراف على الديانات والآراء والنحل والاختيارات واختلاف الناس وقراءة كتبهم (2)، كما لا بد لطالب الحقائق، في نظر ابن حزم، من الاطلاع على القرآن ومعانيه ورتب ألفاظه وأحكامه وحديث النبي (صلى الله عليه وسلم) وسيره الجامعة لجميع الفضائل المحمودة في الدنيا والموصلة إلى خير الآخرة. ولا بد له مع ذلك من مطالعة الأخبار القديمة والحديثة والوقوف على اللغة التي تقرأ الكتب المترجمة بها والتبحر في وجوه المستعمل منها، ولا بد له مع ذللك من مطالعة النحو ويكفيه منه ما يصل به إلى اختلاف المعاني بما يقف عليه من اختلاف الحركات في الألفاظ ومواضع الإعراب منها (3)

\section{الخاتمة}

يتأكد من خلال متابعتنا لبعض تجليات التحاجج والتتاظر في نراث ابن حزم أن المناظرة لم نكن قط في بد المسلمين أداة للاشتغال بالحجاج المذموم والمنازعة المقصودة لذاتها، وإنما كانت وسيلة من وسائل تنمية المعرفة الصحيحة وممارسة العقل السليم بالحجاج الصحيح(4) والجدال المحمود. وهذا ما كثف عنه بوضوح منهج ابن حزم في التحاجج والتتاظر •

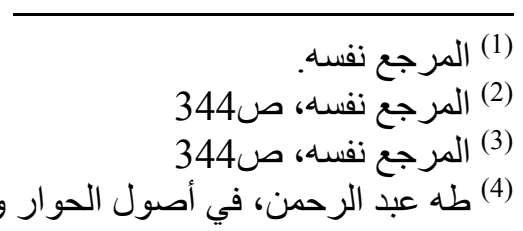




\section{المراجـع}

\section{أولاً: المراجع العربية}

ابن حزم الأندلسي، الإحكام في أصول الأحكام، تحقيق الثيخ أحمد محمد شاكر ، تقديم الدكتور

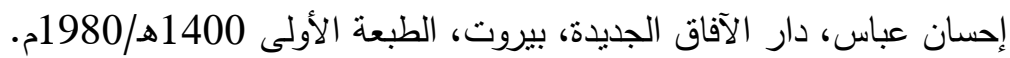

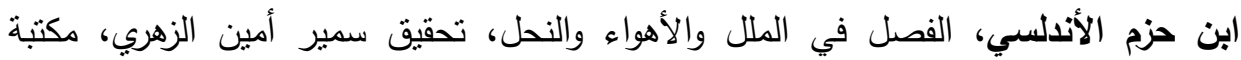

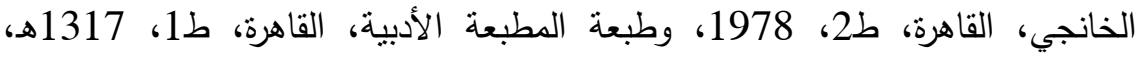

وبتحقيق محمد إبراهيم نصر وعبد الرحمن عميرة، مكتبة عكاظ، جدة، 1982م.

ابن حزم، رسائل ابن حزم الأندلسي (أربعة أجزاء)، تحقيق الدكتور إحسان عباس، المؤسئة

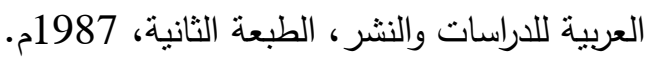

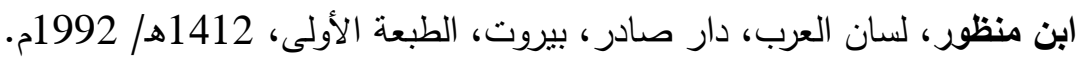

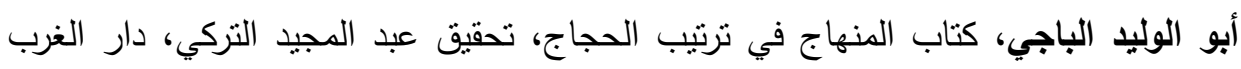

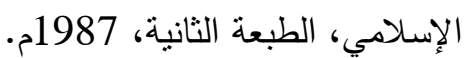

أبو حامد بن محمد الغزالي، إحياء علوم الدين، مكتبة مصطفى البابي، القاهرة، 1358هـ الإنها إسماعيل مصطفى إسماعيل اليوسف، ابن حزم الأندلسي: حياته وفلسفته، رسالة لنيل الماجستير لئه قدمت إلى معهد الآداب الثرقية في جامعة القديس يوسف في بيروت، إنراف الدكتور

$$
\text { أسعد أحمد علي، 1397هـ. }
$$

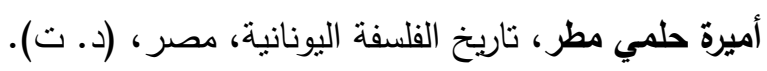
آنخل جنثالث بالثيا، ناريخ الفكر الأندلسي، نقله عن الإسبانية حسين مؤنس، مكتبة الثقافة هيخة

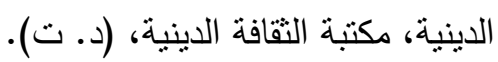

بركات محمد مراد، منهج الجدل والمناظرة في الفكر الإسلامي، منشورات الصدر لخدمات لاتهات الطباعة، القاهرة، الطبعة الأولى مراد، 1990م.

حافظ إسماعيلي علوي (إثراف وتقديم)، الحجاج مفهومه ومجالاته، دراسات نظرية وتطبيقية في

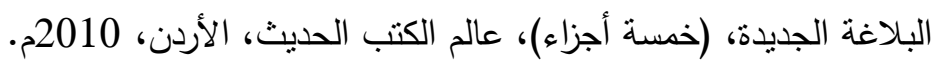
حامد أحمد الدباس، فلسفة الحب والأخلاق عند ابن حزم، دار الإبداع، عمان، 1993م. 
حسان محمد حسان، ابن حزم الأندلسي عصره ومنهجه وفكره التربوي، دار الفكر العربي،

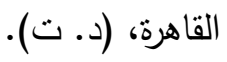

حسين الصديق، المناظرة في الأدب العربي- الإسلامي، مكتبة لبنان ناشرون، الثركة المصرية

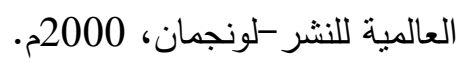

حمد بن إبراهيم العثمان، أصول الجدل والمناظرة في الكتاب والسنة، دار ابن حزم، الطبعة

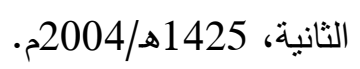

حمو النقاري (تتسيق)، التحاجج طبيعته ومجالاته ووظائفه، جامعة محمد الخامس، منشورات كلية الآداب والعلوم الإنسانية، سلسلة ندوات ومناظرات رقم

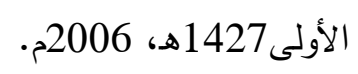

حمو النقاري، منطق الكلام، من المنطق الجدلي الفلسفي إلى المنطق الحجاجي الأصولي، دار

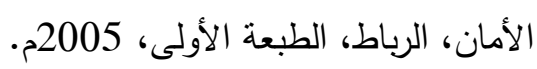

خالد عبد الحليم عبد الرحيم السيوطي، الجدل الديني بين المسلمين وأهل الكتاب بالأندلس (ابن

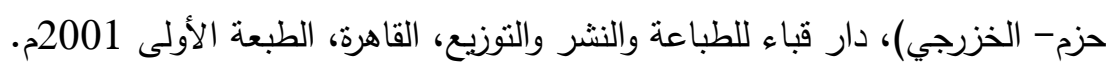
رشيد الراضي، الحجاج والمغالطة، من الحوار في العقل إلى العقل في الحوار، الكتاب الجديد

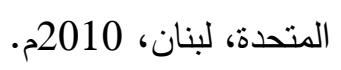

الزركشي، البرهان في علوم القرآن، تحقيق محمد أبو الفضل، دار المعرفة، بيروت، 1972.

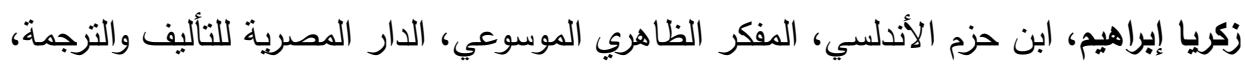

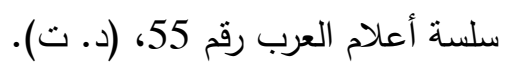

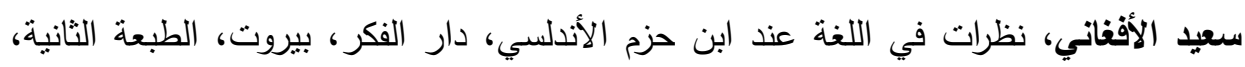

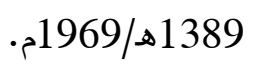

سعيد بنكروم (تسيق)، ابن حزم الأندلسي المنهج والمعرفة، جامعة الحسن الثاني، منشورات

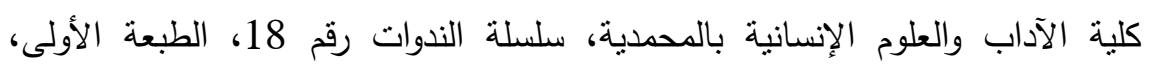

2005

السيوطي، الإتقان في علوم القرآن، عالم الكتب، بيروت، 1972م.

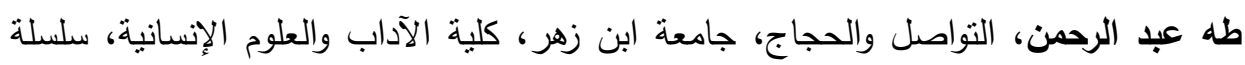

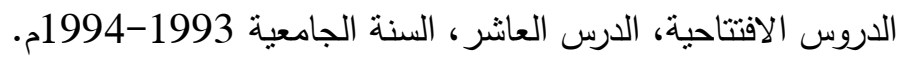


طه عبد الرحمن، في أصول الحوار وتجديد علم الكلام، المركز الثقافي العربي، الطبعة الثانية، .2000

عادل المصطفى، المغالطات المنطقية، المجلس الأعلى للثقافة، مصر ، 2007م.

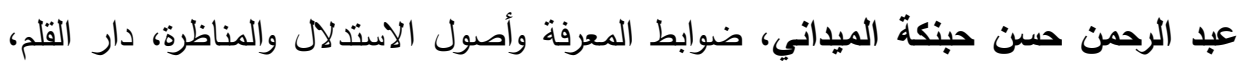

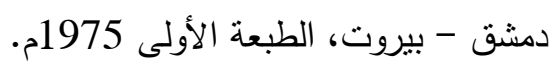

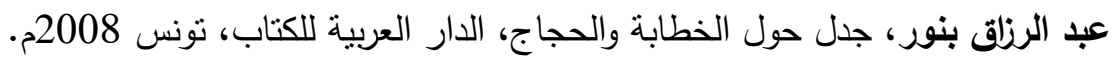

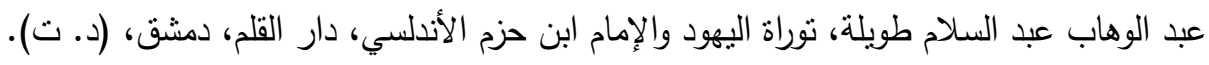

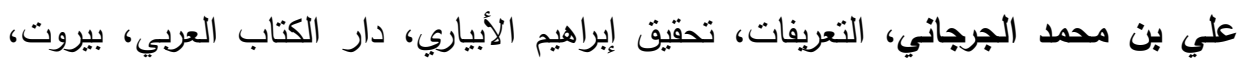
الطبعة الثانية، 1413هـ.

محمد أبو زهرة، ابن حزم حياته وعصره- آراؤه وفقهه، دار الفكر العربي، (د. ت).

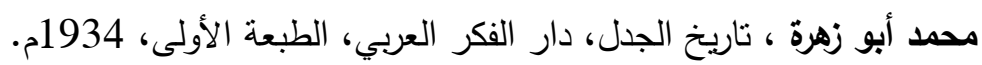

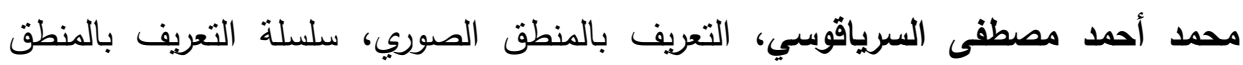

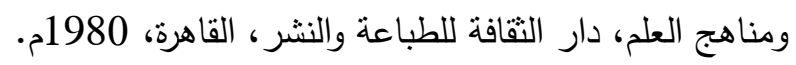
محمد عابد الجابري، نكوين العقل العربي، نقد العقل العربي 1، دار الطليعة، بيروت، الطبعة الأولى 1984م.

محمد عبد الله الشرقاوي، منهج نقد النص بين ابن حزم الأندلسي واسبينوزا، (د. ط)، (د. ت).

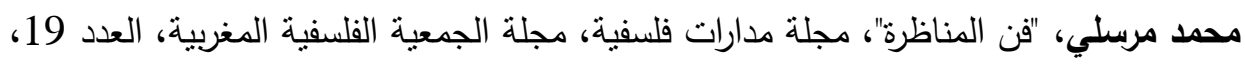
2010 محمود علي حماية، ابن حزم ومنهجه في دراسة الأديان، دار الدعارف، الطبعة الأولى، 1983

موريتس شتينشنيدر، أدب الجدال والدفاع في العربية بين المسلمين والمسيحيين واليهود، ترجمة صلاح عبد العزيز محجوب إدريس، مراجعة وتقديم محمد خليفة حسن، المجلس الأعلى بلى لئل

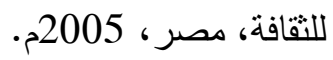
نعمان بوقرة، النظرية اللسانية عند ابن حزم الأندلسي: قراءة نقدية في مرجعيات الخطاب

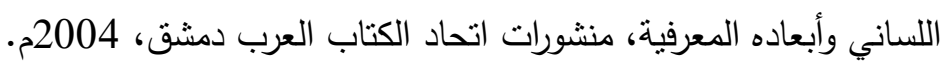


نعمان بوقرة، ابن حزم النص اللاهوتي قراءة في منهج نقد الأديان في ضوء النظرية الحزمية، مجلة فكر ونقد العدد85، السنة، 2007م.

وديع واصف مصطفى، ابن حزم وموقفه من الفلسفة والمنطق والأخلاق، المجع الثقافي بأبو ظبي، 2000م.

\section{ثانيًا: المراجع الإنجليزية}

Blanché. R, Raisonnement, PUF, 1971.

Kahane. H, Logic and contemporary rhetoric, 2d. 1976, Wadsworth Publishing Company, Inc, 1971.

Walton, Douglas, (1991), «les violations des règles du dialogue raisonné », dans Hermann Parret. (dir), la communauté en paroles. Communication, consenus, ruptures, Liège, Mardaga, p245-265. 
حافظ إسماعيلي علوي

\title{
Arguing and Debating \\ The morals of debating and techniques of uncovering fallacies in Ibn Hazm,s tradition
}

\author{
Dr. Hafez Ismail Alawi \\ Qatar University
}

\begin{abstract}
This research attempts to introduce a comprehensive conception of some of arguing and debating conditions in Ibn hazm,s writings that were introduced in some of his books and at the same time to explore the fallacies techniques which he warned of their serious effects in the context of arguing and debating.

My basic goal is to elaborate how the Islamic traditional discourse is rich with methodological approaches that could contribute to an active dialogue between it and modern knowledge in all forms. I have done my best to relate Ibn Hazm's ideas to the contemporary argumentative studies without maximizing or minimizing the importance of any of them.
\end{abstract}

Key words: Arguing and Debating in Islamic heritage, Ibn hazm the Andalusian. 